\title{
Sample Selection Report for the Irradiation and Post Irradiation Examination of Ultra High Burnup Fuel
}

Project Number 32792

D. Jadernas, K. Yueh, M. Bales, D. Wachs, K. Terrani, K. Linton, N. Meacham

January 2018

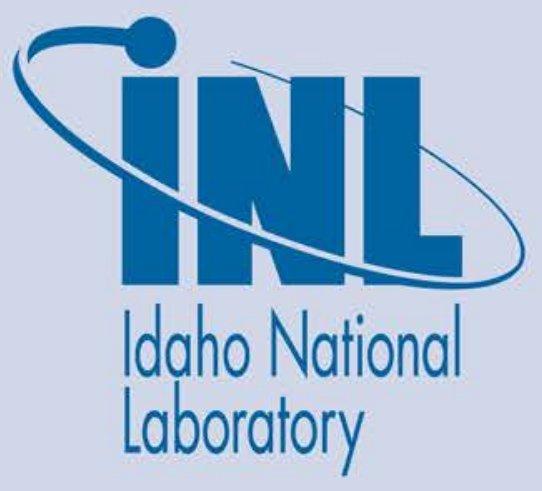

The INL is a U.S. Department of Energy National Laboratory operated by Battelle Energy Alliance 


\section{DISCLAIMER}

This information was prepared as an account of work sponsored by an agency of the U.S. Government. Neither the U.S. Government nor any agency thereof, nor any of their employees, makes any warranty, expressed or implied, or assumes any legal liability or responsibility for the accuracy, completeness, or usefulness, of any information, apparatus, product, or process disclosed, or represents that its use would not infringe privately owned rights. References herein to any specific commercial product, process, or service by trade name, trade mark, manufacturer, or otherwise, does not necessarily constitute or imply its endorsement, recommendation, or favoring by the U.S. Government or any agency thereof. The views and opinions of authors expressed herein do not necessarily state or reflect those of the U.S. Government or any agency thereof. 
INL/EXT-17-44054

Revision 1

\title{
Sample Selection Report for the Irradiation and Post Irradiation Examination of Ultra High Burnup Fuel
}

\author{
D. Jadernas, K. Yueh, M. Bales, D. Wachs, K. Terrani, K. Linton, N. Meacham
}

January 2018

Idaho National Laboratory Idaho Falls, Idaho 83415

http://www.inl.gov 
This page intentionally left blank. 


\section{SUMMARY}

This report summarizes the available data for fuel pins available to the project and selects samples for integral LOCA tests, heating tests, and irradiation in the Advanced Test Reactor (ATR) at the Idaho National Laboratory (INL). 
This page intentionally left blank. 


\section{CONTENTS}

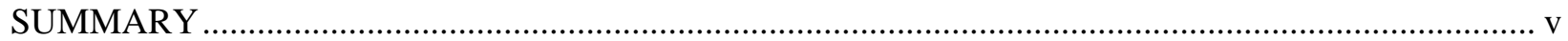

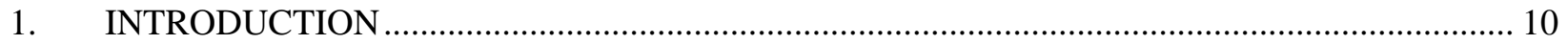

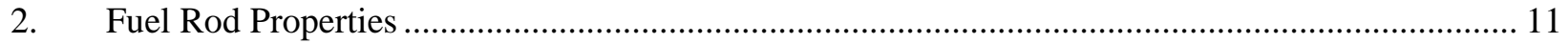

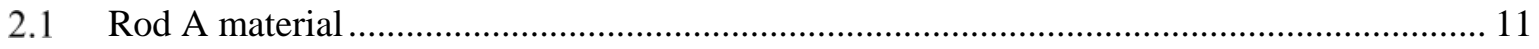

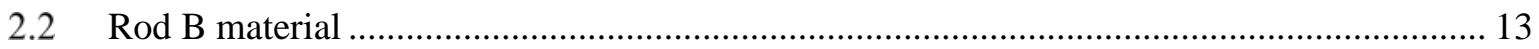

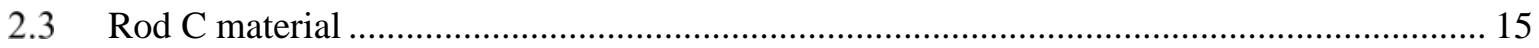

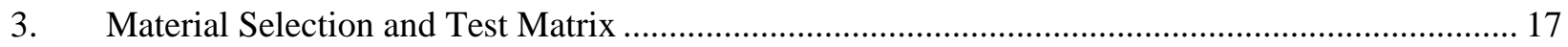

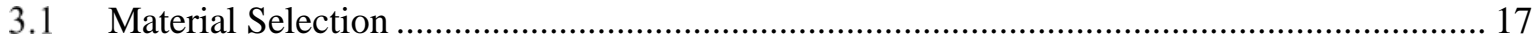

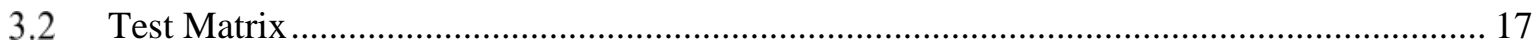

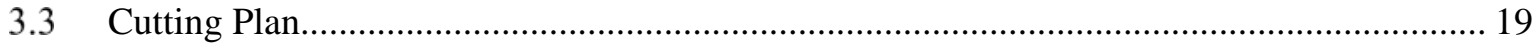

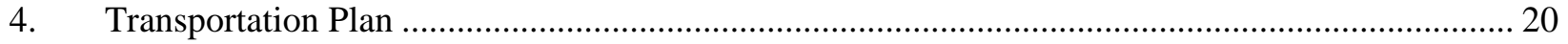

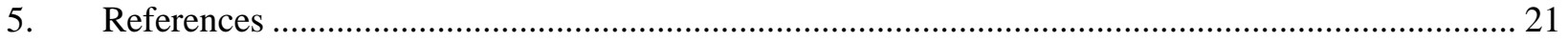




\section{FIGURES}

Figure 1. Probable transition zone between fuel that produces fine fragmentation during a loss of coolant accident and fuel rods that do not [5]

Figure 2. Gross gamma scan for rod A8 (A/G 649). The available segments shown in blue and the original segment cutting plan is shown in green...

Figure 3. Gross gamma scan for rod P16 (A/G 650). The available segments shown in blue and the original segment cutting plan is shown in green.

Figure 4. Gross gamma scan for rod B16 (A/G 651). The available segments shown in blue and the original segment cutting plan is shown in green.

Figure 5. Power History for rod E02 with A/G number 605. Reproduced from [1].

Figure 6. Axial burnup distribution along the active fuel stack length for rod B05 from the same assembly and with the same burnup as rod E02 (A/G 605). Available segments in green. Reproduced from [2].

Figure 7. Gross gamma scan for segment 605B and the available segments shown in green. Supplied by ORNL.

Figure 8. Axial burnup profile as mesasured using dissolution techniques summarized in [4] for rod 536. The average burnup in the 'flat' region of the rod was calculated to 52 $\mathrm{MWd} / \mathrm{kgU}$. 16

Figure 9. Proposed sample selection from the available segments (not to scale). 18

Figure 10. Cutting plan and segment designations after cutting (not to scale). 19

\section{TABLES}

Table 1. Data describing the fuel rods available to this project. Data supplied by ORNL and INL

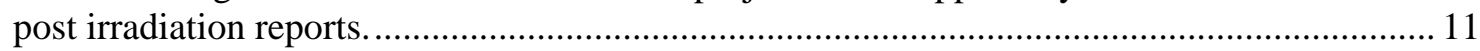

Table 2. Data describing the Rod A segments available to this project. Supplied by ORNL..................... 11

Table 3. Data describing the Rod B segments available to this project. Supplied by ORNL.................... 13

Table 4. Data describing the Rod C segments available to this project. Supplied by ORNL.................... 15

Table 5. Summary of the material selected for this project. ................................................................... 17

Table 6. Summary of the selected samples for this project...................................................................... 18

Table 7. Cutting plan and segment designations after cutting. .............................................................. 19

Table 8. Transportation plan with segment lengths to be shipped to INL from ORNL............................. 20 
This page intentionally left blank. 


\section{Sample Selection Report for the Irradiation and Post Irradiation Examination of Ultra High Burnup Fuel}

\section{INTRODUCTION}

This project is intended to generate sufficient test data to inform industry and regulatory agencies to enable the disposition of the fuel fragmentation issue in standard Light Water Reactor (LWR) fuel designs irradiated to high burnup. This will require reconditioning of irradiated fuel in a reactor at specific power levels and simulated loss-of-coolant accident (LOCA) testing in hot-cell furnaces.

This report describes the sample selection for the project. In order to make the selection the most important parameters are burnup and last cycle power. The following sections will describe attributes of the available fuel rods, where fuel segments elevation, and a proposed cutting plan.

The aim of the sample selection is, to the extent possible, select samples that allow the project to close the data gap illustrated as in Figure 1. The figure shows the probable transition zone between fuel rods that produces fine fragmentation during a loss of coolant accident and fuel that do not.

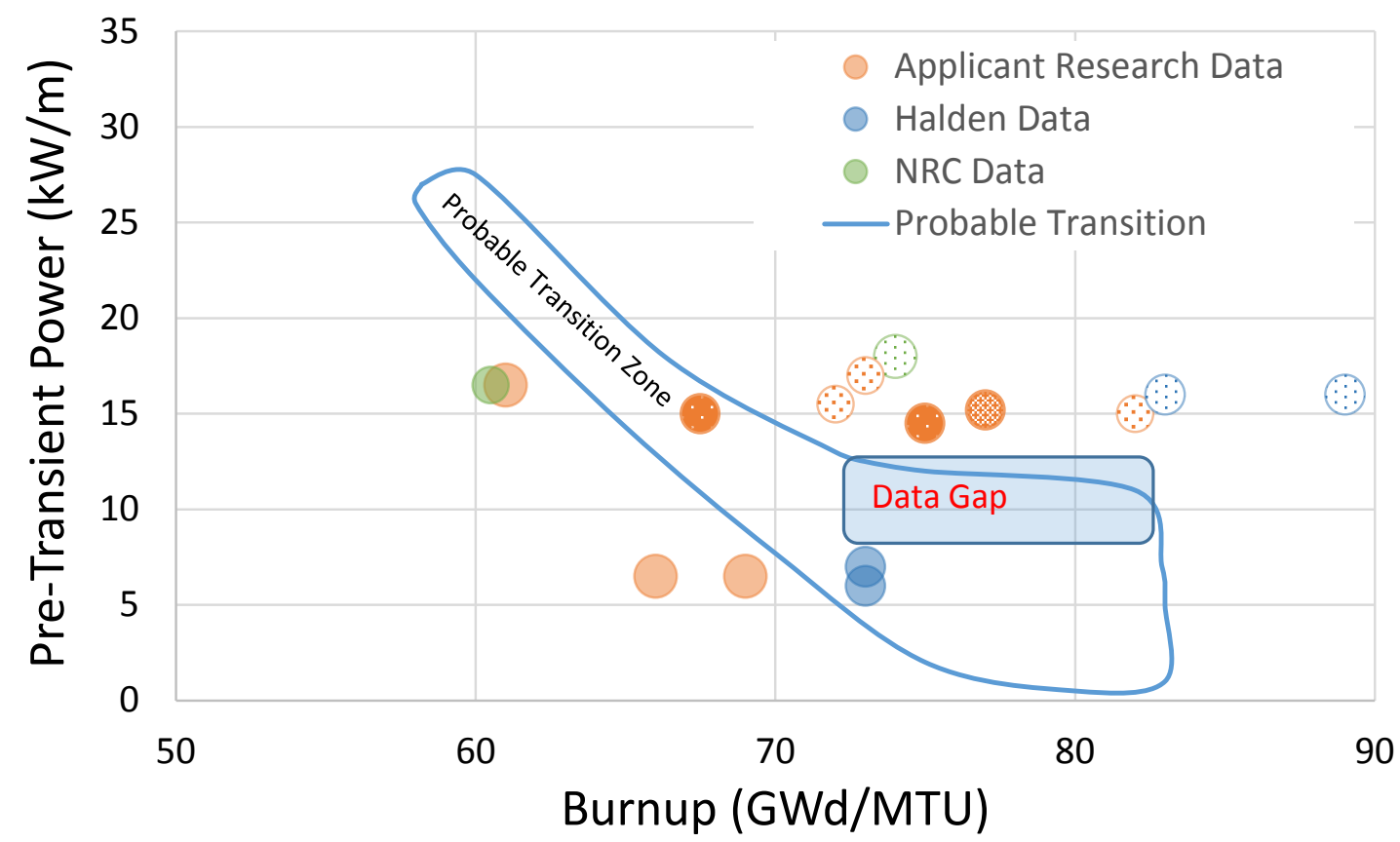

Figure 1. Probable transition zone between fuel that produces fine fragmentation during a loss of coolant accident and fuel rods that do not [5]. 


\section{Fuel Rod Properties}

This section summarizes the fuel material available to the project. Table 1 summarizes data on fuel rods available at Oak Ridge National Laboratory (ORNL). The following sections will provide more detailed data for each of the selected fuel rods.

Table 1. Data describing the fuel rods available to this project. Data supplied by ORNL and INL post irradiation reports.

\begin{tabular}{|c|c|c|c|}
\hline Fuel rod designation & $\operatorname{Rod} \mathrm{A}$ & $\operatorname{Rod} B$ & Rod C \\
\hline Reator Type & PWR & PWR & PWR \\
\hline Initial Enrichment [wt-\% U-235] & 4.2 & 2.9 & 4 \\
\hline Burnup [MWd/kgU] & $63-70$ & $63-67$ & $48-50$ \\
\hline Discharge Year & 2004 & 1995 & 1997 \\
\hline Nominal OD [mm] & 9.5 & 10.76 & 10.92 \\
\hline Initial Wall Thickness [mm] & 0.57 & 0.76 & 0.69 \\
\hline OD Oxide $[\mu \mathrm{m}]$ & $<20$ & $<100$ & $<50$ \\
\hline Hydrogen concentration [wt-ppm] & $<120$ & $<800$ & $<300$ \\
\hline Fission Gas Release data available & Yes & Yes & Yes \\
\hline Power history available & Yes & Yes & Unknown \\
\hline
\end{tabular}

\subsection{Rod A material}

Rod A material is comprised of material from three different sister fuel rods with similar irradiation history. Table 2 summarizes some attributes of the parent rods and material availability [4]. It is estimated that the last cycle power was above $15 \mathrm{~kW} / \mathrm{m}$ for all rods and that the upper parts of the rods experienced an even higher last cycle power.

Figure 2-Figure 4 shows the gross gamma scans for rods A8, P16 and B16 overlaid with the original cutting plan for each rod in green. The blue bars show the locations of the available segments. It was difficult to determine the available segment's exact axial position, particularly for rod B16. No axial burnup profile was obtained but it can be assumed that the burnup in the 'flat' regime is around $10 \%$ higher than the rod average burnup.

Table 2. Data describing the Rod A segments available to this project. Supplied by ORNL.

\begin{tabular}{|c|c|c|c|c|c|}
\hline A/G No. & Segment ID & Length (in.) & Rod ID & Fission Gas Release (\%) & Avg. Burnup MWd/kgU \\
\hline \multirow{3}{*}{649} & C1 & 12.0 & \multirow{3}{*}{ A8 } & \multirow{3}{*}{16.1} & \multirow{3}{*}{75.1} \\
\hline & D2 & 12.0 & & & \\
\hline & E2 & 12.0 & & & \\
\hline \multirow{3}{*}{650} & $\overline{\mathrm{C} 1}$ & 12.0 & \multirow{3}{*}{ P16 } & \multirow{3}{*}{9.8} & \multirow{3}{*}{67.3} \\
\hline & D2 & 12.0 & & & \\
\hline & E2 & 12.0 & & & \\
\hline \multirow{9}{*}{651} & $\overline{\mathrm{B} 3}$ & 1.0 & \multirow{9}{*}{ B16 } & \multirow{9}{*}{12.0} & \multirow{9}{*}{72.9} \\
\hline & C1 & 2.1 & & & \\
\hline & D2 & 4.1 & & & \\
\hline & D4 & 1.0 & & & \\
\hline & E1 & 4.2 & & & \\
\hline & E4 & 3.4 & & & \\
\hline & E7 & 4.2 & & & \\
\hline & F3 & 1.6 & & & \\
\hline & G & 25.5 & & & \\
\hline
\end{tabular}




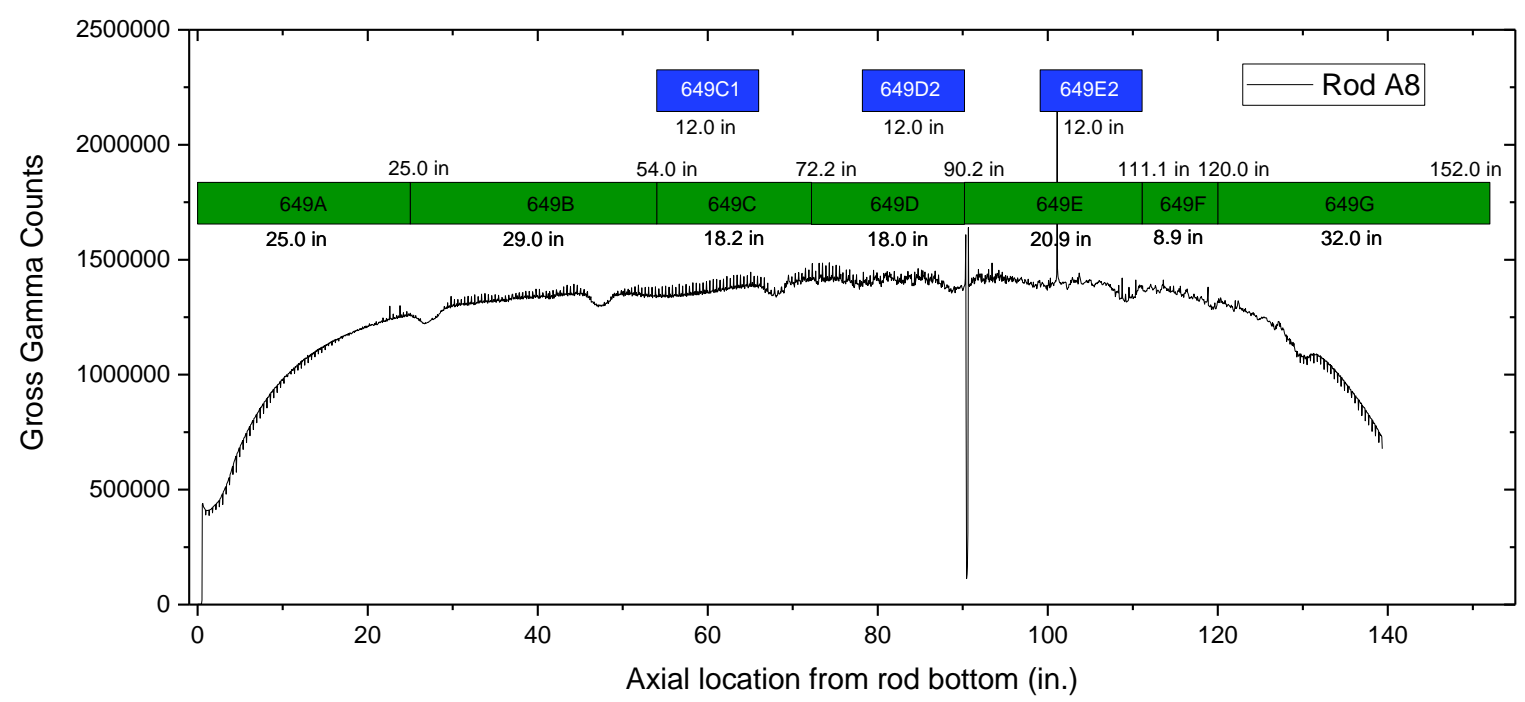

Figure 2. Gross gamma scan for rod A8 (A/G 649). The available segments shown in blue and the original segment cutting plan is shown in green.

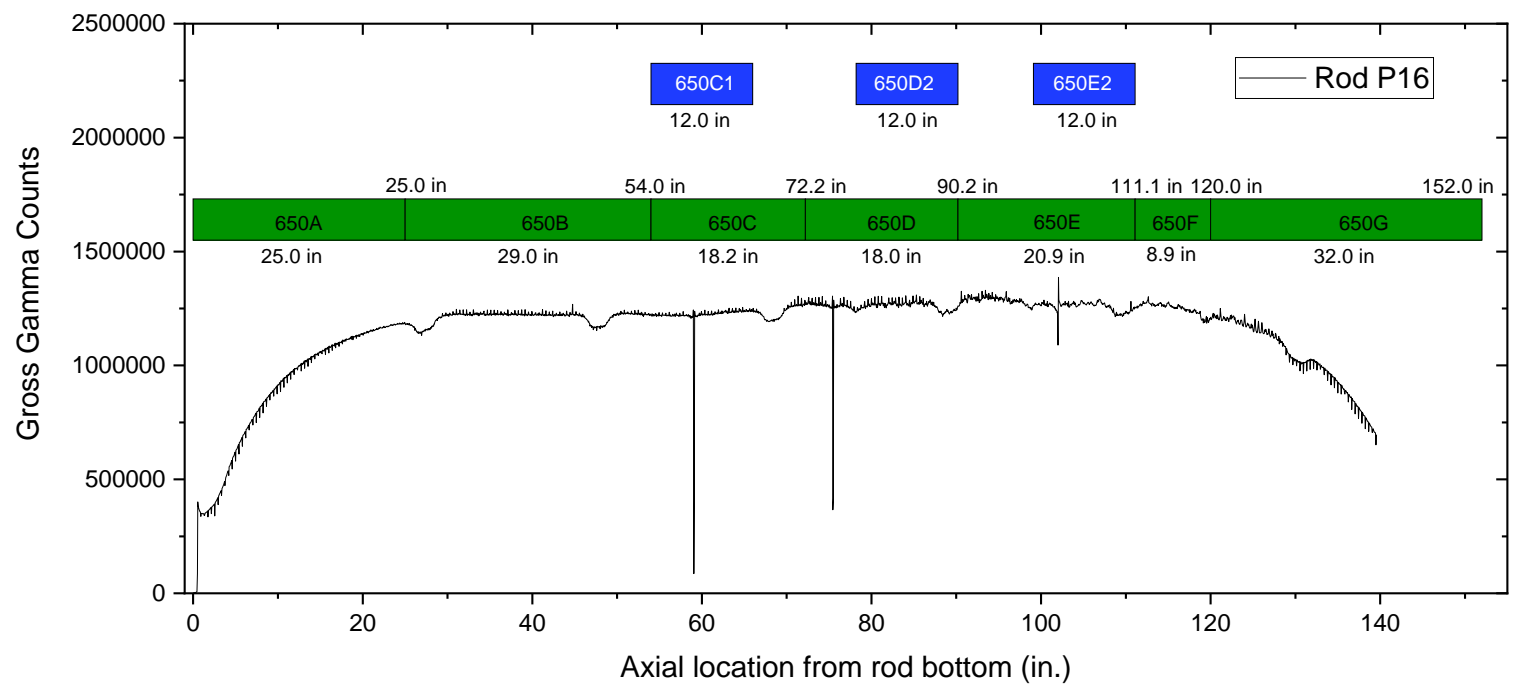

Figure 3. Gross gamma scan for rod P16 (A/G 650). The available segments shown in blue and the original segment cutting plan is shown in green. 


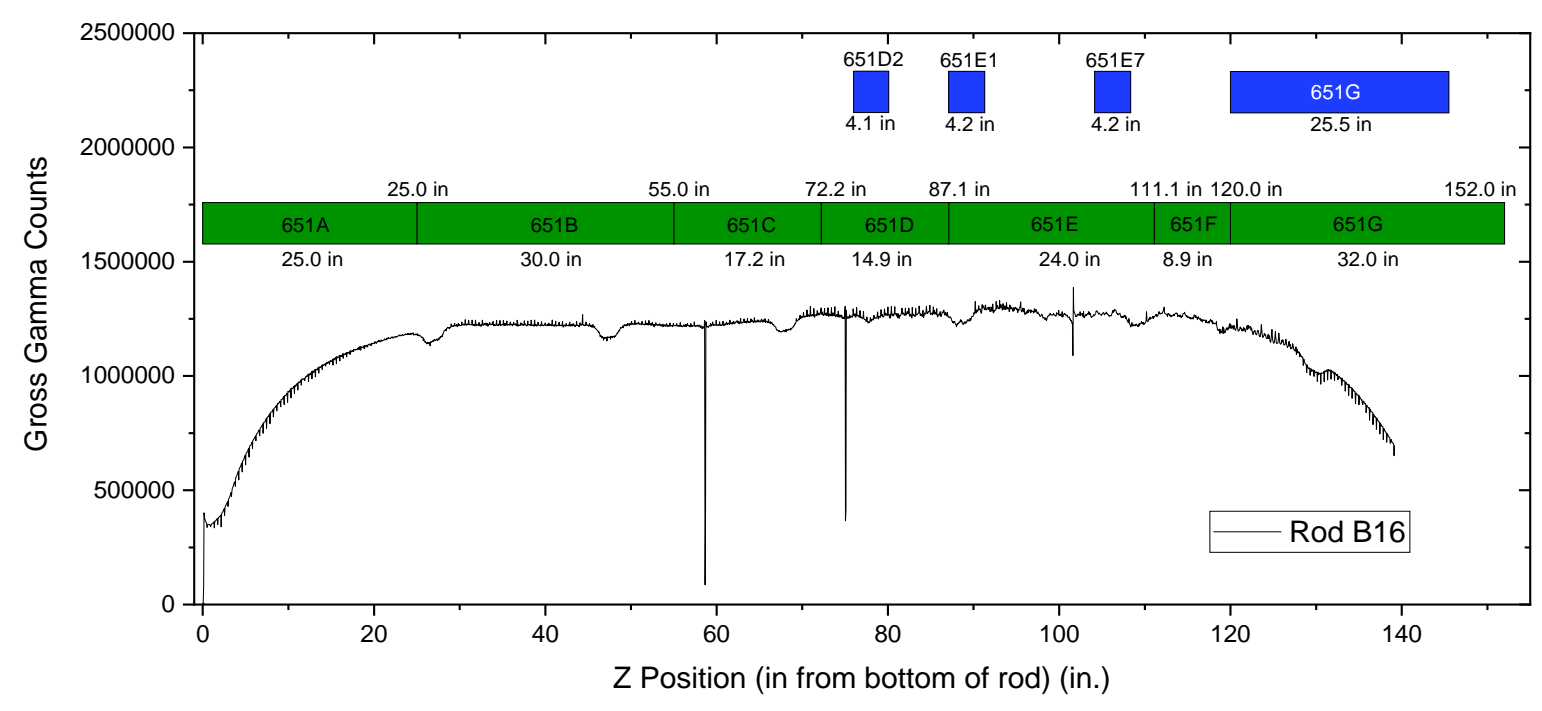

Figure 4. Gross gamma scan for rod B16 (A/G 651). The available segments shown in blue and the original segment cutting plan is shown in green.

\subsection{Rod B material}

Rod B material consists of a 20" and a 5.4" piece of fuel from the upper part of the original fuel rod with current identification number A/G 605 section B. A report has been published containing the design, operation, and performance data for this rod in [1]. In reference 1, the rod designation is E02 from assembly S-15H (originally from G-38) and it includes the measured fission gas release during base irradiation, 2.1\%. Table 3 summarizes some attributes of the parent rod B and material availability. The power history for the rod has been reproduced in Figure 5.

Table 3. Data describing the Rod B segments available to this project. Supplied by ORNL.

\begin{tabular}{|c|c|c|c|c|c|}
\hline A/G No. & Segment ID & Length (in.) & Rod ID & Fission Gas Release (\%) & Avg. Burnup MWd/kgU \\
\hline 605-B8/9 & 20.1 & E02 & 2.1 & 66.5 & 10.5 \\
\hline 605-B7 & 5.4 & E02 & 2.1 & 66.5 & 10.5 \\
\hline
\end{tabular}

The axial burnup profile for a sister rod, B05, was retrieved and reproduced in Figure 6. It is assumed that since rod E05 was irradiated in the same fuel bundle as rod E02 (used in this work) the same burnup profile can be used also for this rod.

Section 605B was cut from the upper part of the rod. The remaining pieces from this segment can be seen in Figure 7. The cutting diagram [2] shows that segment 605B was cut between 103-136 inches from the rod bottom end. The top segment (605A) was 16” long. The bottom end plug is 0.6 ” and the top end plug including the plenum is 7.2”. The available segments experienced a relatively flat burnup profile region ranging from $69 \mathrm{MWd} / \mathrm{kgU}$ at the top of the fuel segment to $72 \mathrm{MWd} / \mathrm{kgU}$ at the lower part of the segment. Furthermore, it is likely that the local power in the upper part of the rod has been slightly higher than what is presented in Figure 5.

According to the cutting plan, there are no spacer grids present along the available fuel segments. 


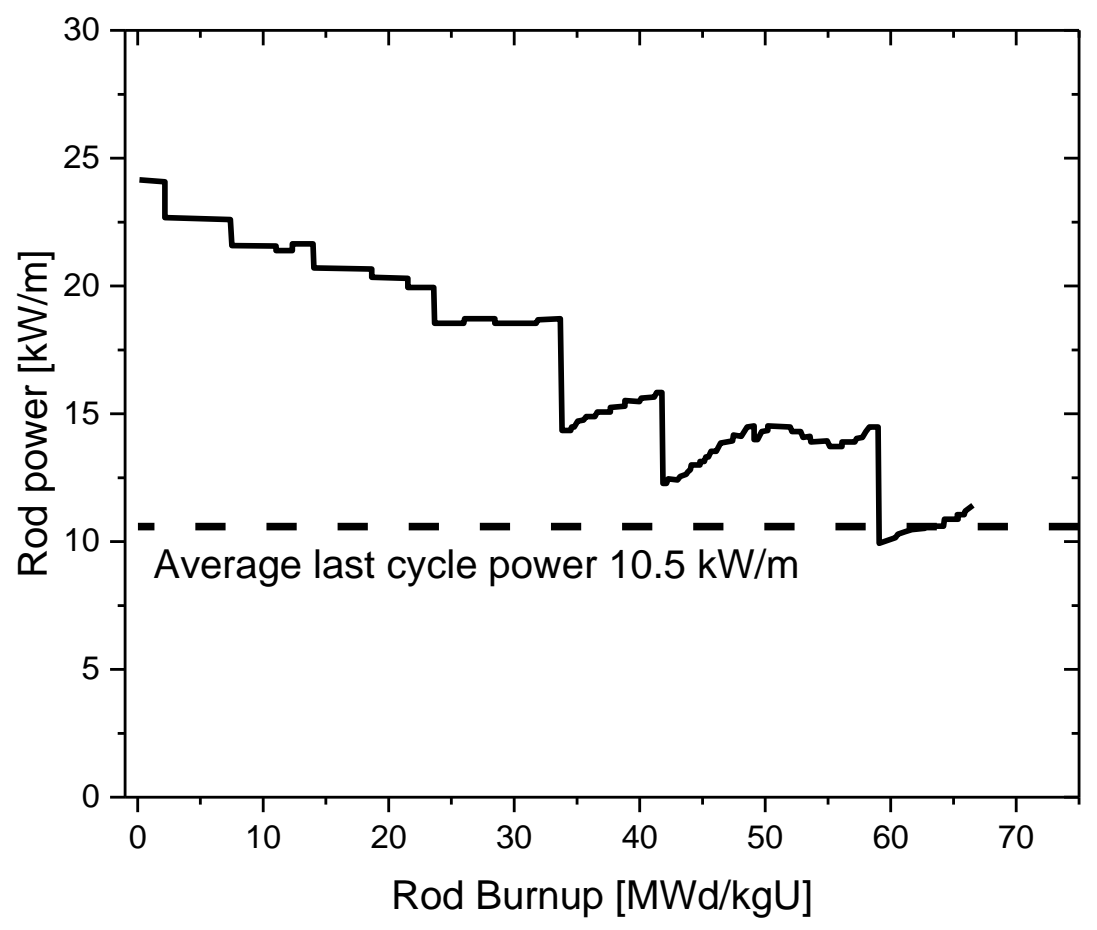

Figure 5. Power History for rod E02 with A/G number 605. Reproduced from [1].

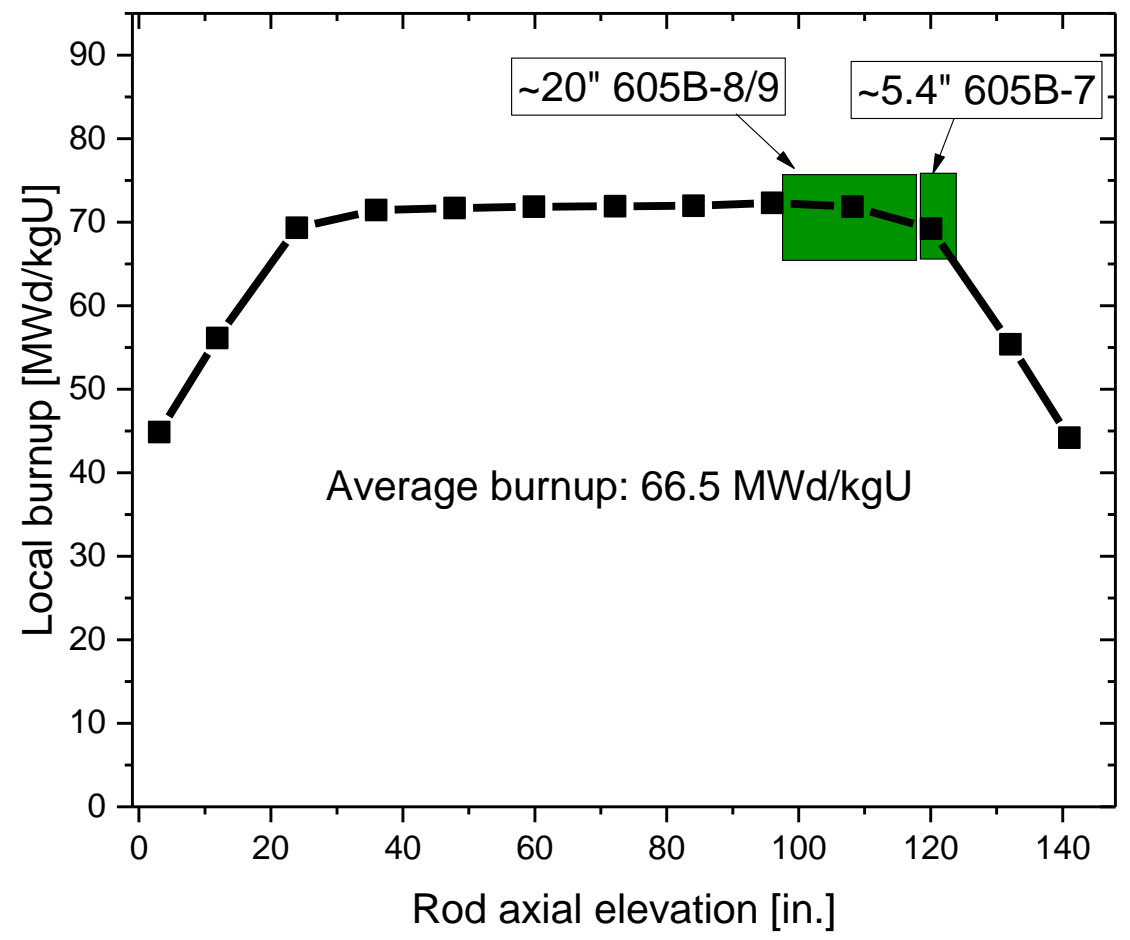

Figure 6. Axial burnup distribution along the active fuel stack length for rod B05 from the same assembly and with the same burnup as rod E02 (A/G 605). Available segments in green. Reproduced from [2]. 


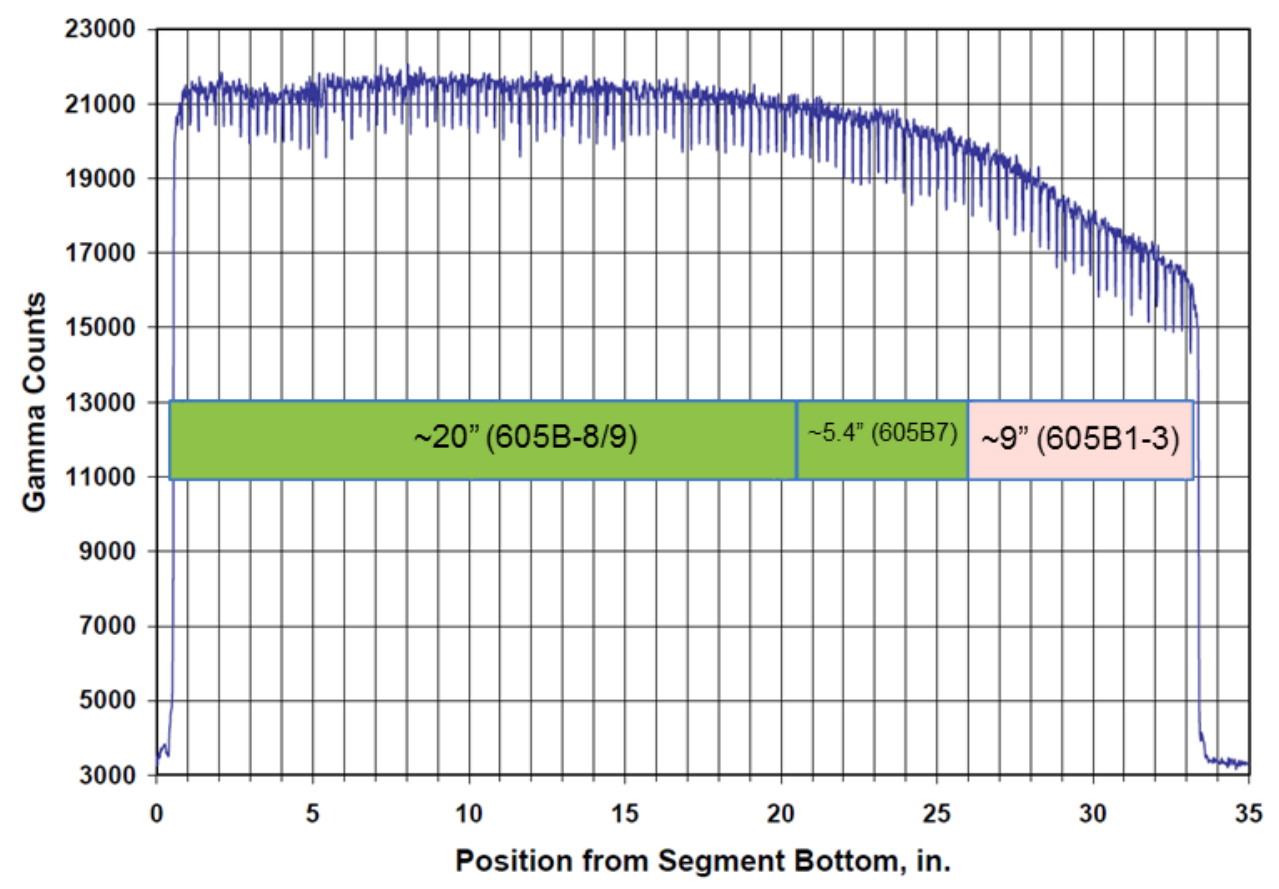

Figure 7. Gross gamma scan for segment 605B and the available segments shown in green. Supplied by ORNL.

\subsection{Rod C material}

Very little data is available for the fuel segments from Rod C (two fuel rods). A summary of the data available for the segments is presented in Table 3. The burnup profile is plotted for rod 536, see Figure 8. The calculated average burnup in the 'flat' region of the rod was $52 \mathrm{MWd} / \mathrm{kgU}$. No gamma scan data, fission gas release data or power history is currently available for rod 536. The calculated average burnup in the flat burnup region for rod 616 is calculated to $51 \mathrm{MWd} / \mathrm{kgU}$. It should be noted that these values are estimates.

The axial location of the available segment could not be determined from the available data. However, assuming that the same method was used to designate the segments as for the other rods, it can be assumed that segments B, C, D and E should be positioned in the axial center region of the fuel rods where the burnup profile is relatively flat.

Table 4. Data describing the Rod C segments available to this project. Supplied by ORNL.

\begin{tabular}{|c|c|c|c|c|c|}
\hline A/G No. & Segment ID & Length (in.) & Rod ID & Fission Gas Release (\%) & Avg. Burnup MWd/kgU \\
\hline \multirow{5}{*}{616} & A-3 & 19.6 & & & \\
& B-1 & 12.0 & & & \\
& B-3 & 5.5 & & & \\
& B-5 & 8.7 & NJ05YU-D5 & N/A & \\
& C1 & 13.0 & & & \\
& D & 19.0 & & & \\
& E & 31.0 & & & \\
\hline \multirow{3}{*}{536} & B-1A1 & 11.0 & & & \\
& C2D-3 & 13.4 & NJ05YU-H6 & N/A & \\
\hline
\end{tabular}

*Estimated from values in [4]. 


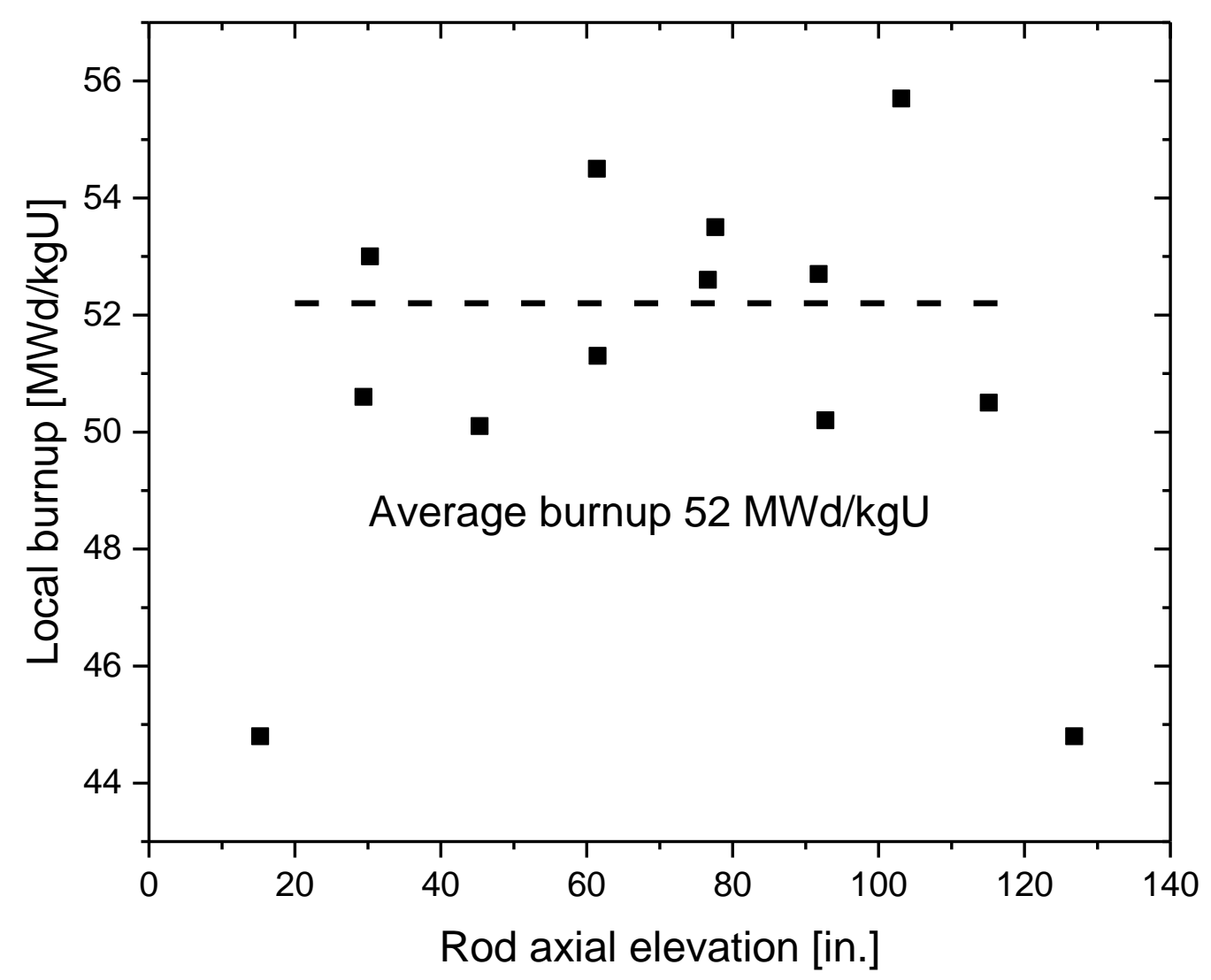

Figure 8. Axial burnup profile as mesasured using dissolution techniques summarized in [4] for rod 536. The average burnup in the 'flat' region of the rod was calculated to $52 \mathrm{MWd} / \mathrm{kgU}$. 


\section{Material Selection and Test Matrix}

\subsection{Material Selection}

Table 5 represents the selected samples for the project. Please note that the final samples will be slightly shorter since cutting will consume material.

Table 5. Summary of the material selected for this project.

\begin{tabular}{|c|c|c|c|c|c|c|}
\hline Rod & $\begin{array}{c}\text { Segment } \\
\text { ID }\end{array}$ & $\begin{array}{c}\text { Length } \\
\text { (in.) }\end{array}$ & $\begin{array}{c}\text { Original } \\
\text { Rod ID }\end{array}$ & $\begin{array}{c}\text { Fission Gas } \\
\text { Release (\%) }\end{array}$ & $\begin{array}{c}\text { Avg. Burnup } \\
\text { MWd/kgU }\end{array}$ & $\begin{array}{c}\text { Last Cycle } \\
\text { Power (kW/m) }\end{array}$ \\
\hline A & $649-C 1$ & 12.0 & A8 & 16.1 & 75.1 & $>15$ \\
A & $650-C 1$ & 12.0 & P16 & 9.8 & 67.3 & $>15$ \\
\hline A & $650-D 2$ & 12.0 & P16 & 9.8 & 67.3 & $>15$ \\
\hline A & $650-E 2$ & 12.0 & P16 & 9.8 & 67.3 & $>15$ \\
\hline B & $605-B 8 / 9$ & 20.1 & E02 & 2.1 & 66.5 & 10.5 \\
\hline B & $605-B 7$ & 5.4 & E02 & 2.1 & 66.5 & 10.5 \\
\hline C & $616-C 1$ & 13.0 & NJ05YU-D5 & N/A & 50.9 & N/A \\
\hline C & $616-D$ & 19.0 & NJ05YU-D5 & N/A & 50.9 & N/A \\
\hline
\end{tabular}

\subsection{Test Matrix}

The test matrix on this project consists of the following:

- 2 LOCA test segments

- 8 ATR segments for re-irradiation

- 4 heating tests

- Archive material for microstructural characterization

Figure 9 visualizes the selected sample's positions on the available fuel rod segments. It is of most importance that the LOCA-X and ATR-X have the specified length. End plugs will be welded on these two types of samples and if the welding procedure fails, they may end up being shorter than specified, resulting in the need for longer end plugs to fit the experiment design in the ATR. The detailed end plug design requirements will be specified in a subsequent report. LOCA testing will occur at ORNL Irradiated Fuel Examination Laboratory (IFEL) using the Severe Accident Testing Station (SATS). The rest of the samples will be shipped to the INL. Heating tests will occur in the blister furnace at the Hot Fuel Examination Facility (HFEF) at the Material and Fuels Complex (MFC). Irradiation will occur in the Advanced Test Reactor. Microstructural characterization will occur at either the MFC or the Center for Advanced Energy Studies (CAES). Microstructural characterization may also occur at Oak Ridge National Laboratory. Therefore, fuel material will also be retained at ORNL. 
Table 6. Summary of the selected samples for this project.

\begin{tabular}{|c|c|c|c|c|c|c|}
\hline Sample ID & $\begin{array}{c}\text { Rod } \\
\text { Designation }\end{array}$ & $\begin{array}{c}\text { Segment } \\
\text { ID }\end{array}$ & $\begin{array}{c}\text { Sample } \\
\text { Length (in.) }\end{array}$ & $\begin{array}{c}\text { Avg. Burnup } \\
\text { MWd/kgU }\end{array}$ & $\begin{array}{c}\text { Last Cycle } \\
\text { Power (kW/m) }\end{array}$ & $\begin{array}{c}\text { Fission Gas } \\
\text { Release (\%) }\end{array}$ \\
\hline LOCA-1 & A & $650 \mathrm{D} 2$ & 12.0 & 73 & $>15$ & 9.8 \\
\hline LOCA-2 & B & $605 B-8 / 9$ & 12.0 & $69-72$ & 10.5 & 2.1 \\
\hline Heating-1 & A & $649 C 1$ & 1.0 & 82 & $>15$ & 16.1 \\
\hline Heating-2 & A & $650 \mathrm{E} 2$ & 2.0 & 73 & $>15$ & 9.8 \\
\hline Heating-3 & B & $605 B-8 / 9$ & 2.0 & $69-72$ & 10.5 & 2.1 \\
\hline Heating-4 & A & $650 C 1$ & 2.0 & 73 & $>15$ & 9.8 \\
\hline ATR-1 & A & $649 C 1$ & 5.0 & 82 & $>15$ & 16.1 \\
\hline ATR-2 & A & $649 C 1$ & 5.0 & 82 & $>15$ & 16.1 \\
\hline ATR-3 & A & $650 C 1$ & 5.0 & 73 & $>15$ & 9.8 \\
\hline ATR-4 & A & $650 C 1$ & 5.0 & 73 & $>15$ & 9.8 \\
\hline ATR-5 & B & $605 B-8 / 9$ & 5.0 & $69-72$ & 10.5 & 2.1 \\
\hline ATR-6 & B & $605 B 7$ & 5.0 & $69-72$ & 10.5 & 2.1 \\
\hline ATR-7 & C & $616 C 1$ & 5.0 & 51 & N/A & N/A \\
\hline ATR-8 & C & $616 \mathrm{D}$ & 5.0 & 51 & N/A & N/A \\
\hline Met-1 & A & $649 C 1$ & 1.0 & 82 & $>15$ & 16.1 \\
\hline Met-2 & A & $650 C 1$ & 1.0 & 73 & $>15$ & 9.8 \\
\hline Met-3 & A & $650 E 2$ & 1.0 & 73 & $>15$ & 9.8 \\
\hline Met-4 & B & $605 B-8 / 9$ & 1.0 & $69-72$ & 10.5 & 2.1 \\
\hline Met-5 & C & $616 C 1$ & 1.0 & 51 & N/A & N/A \\
\hline Met-6 & C & $616 D$ & 1.0 & 51 & N/A & N/A \\
\hline
\end{tabular}

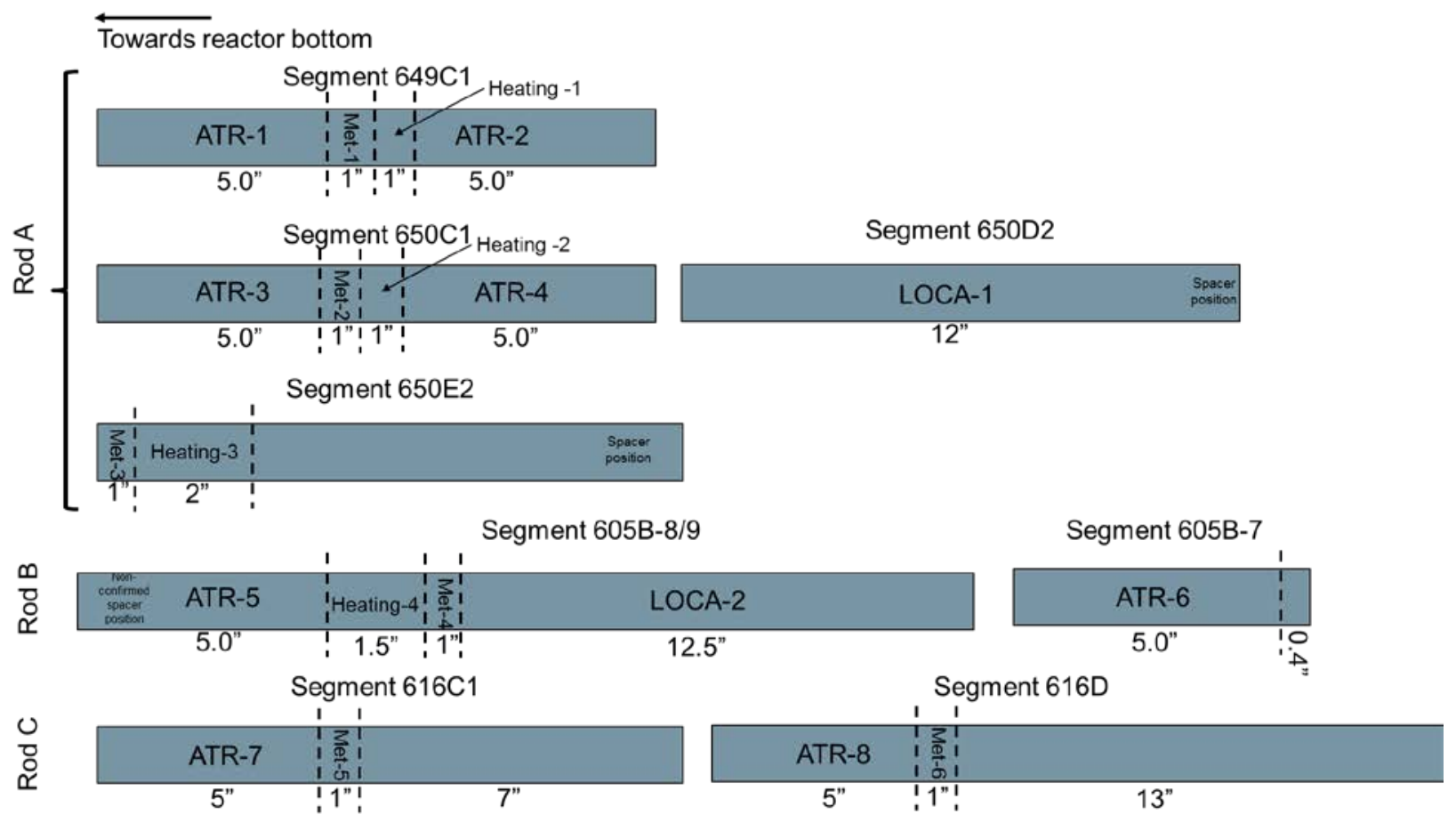

Figure 9. Proposed sample selection from the available segments (not to scale). 


\subsection{Cutting Plan}

Given the material selected in Section 3.1, the following cutting plan is proposed. The LOCA-X and ATR-X segments will be cut at ORNL. Where enough material exists on the existing segments, the cutting of the Heating-X and Met-X samples will take place at INL. This will allow INL to gamma scan the segments and determine the optimal pellet-pellet interface locations prior to cutting the metallography and Heating test samples. The Rod C metallography samples will be cut at ORNL (see figure 10). It is also of importance to know which side of the segment that is towards the bottom of the reactor to make sure the samples are not cut in a spacer grid location.

Table 7. Cutting plan and segment designations after cutting.

\begin{tabular}{|c|c|c|c|}
\hline Segment ID (after cutting) & Samples & Segment ID & Sample Length (in.) \\
\hline 650D2-L1 & LOCA-1 & $650 \mathrm{D} 2$ & 12.0 \\
\hline 605B8/9-L2 & LOCA-2 & $605 \mathrm{~B}-8 / 9$ & 12.5 \\
\hline 649C1-A1 & ATR-1 & $649 \mathrm{C} 1$ & 5.0 \\
\hline 649C1-A2 & ATR-2 & $649 \mathrm{C} 1$ & 5.0 \\
\hline 649C1-A3 & ATR-3 & $649 \mathrm{C} 1$ & 5.0 \\
\hline 649C1-A4 & ATR-4 & $649 \mathrm{C} 1$ & 5.0 \\
\hline 605B8/9-A5 & ATR-5 & $605 \mathrm{~B}-8 / 9$ & 5.0 \\
\hline 605B8/9-A6 & ATR-6 & $605 \mathrm{~B}-8 / 9$ & 5.0 \\
\hline 616C1-A7 & ATR-7 & $616 \mathrm{C} 1$ & 5.0 \\
\hline 616D-A8 & ATR-8 & $616 \mathrm{D}$ & 5.0 \\
\hline 649C1-M1\&H1 & Met-1 \& Heating-1 & $649 \mathrm{C} 1$ & 2.0 \\
\hline 650C1-M2\&H2 & Met-2 \& Heating-2 & $650 \mathrm{C} 1$ & 2.0 \\
\hline 650E2-M3\&H3 & Met-3 \& Heating-3 & $605 \mathrm{E} 2$ & 3.0 \\
\hline 6058/9-M4\&H4 & Met-4 \& Heating-4 & $605 \mathrm{~B}-8 / 9$ & 2.5 \\
\hline 616C1-M5 & Met-5 & $616 \mathrm{C1}$ & 1.0 \\
\hline 616D-M6 & Met-6 & $616 \mathrm{D}$ & 1.0 \\
\hline
\end{tabular}

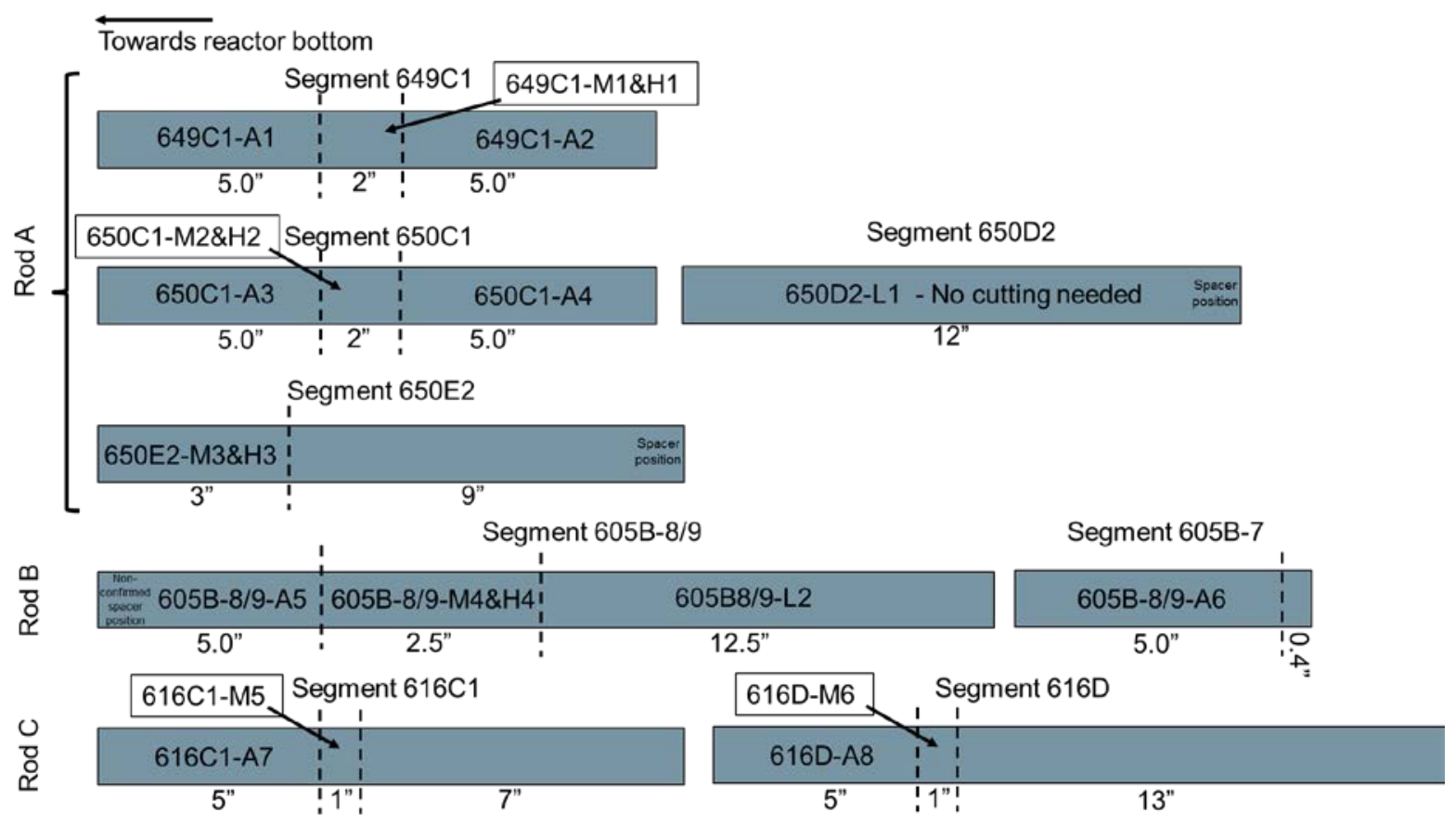

Figure 10. Cutting plan and segment designations after cutting (not to scale). 


\section{Transportation Plan}

All segments that are identified in and cut according to the cutting plan in Section 3.2 will be shipped to INL except the segments for LOCA testing, 650D2-L1 and 605B-8/9-L2. The unmarked residual segments in Figure 10 will remain at ORNL. The complete list of samples that will be transported to INL is summarized in Table 6.

It should be noted that endcaps will be welded on to the ATR segments. This results in that even though the ATR-X active fuel stack length is only maximum 5" long the total sample shipped will be 6.831" including endcaps. The table also show the burnup and the discharge year of each segment as input for nuclide specific inventory calculations if needed for the transport.

Table 8. Transportation plan with segment lengths to be shipped to INL from ORNL.

\begin{tabular}{|c|c|c|c|c|c|c|c|}
\hline $\begin{array}{c}\text { Segment } \\
\text { Specimen ID }\end{array}$ & $\begin{array}{c}\text { Containing } \\
\text { Samples }\end{array}$ & $\begin{array}{c}\text { Original } \\
\text { Segment ID }\end{array}$ & $\begin{array}{c}\text { Specimen } \\
\text { Length (in.) }\end{array}$ & $\begin{array}{c}\text { Fueled } \\
\text { Length (in.) }\end{array}$ & $\begin{array}{c}\text { Avg. Burnup } \\
\text { MWd/kgU }\end{array}$ & $\begin{array}{c}\text { Discharge } \\
\text { Year }\end{array}$ & Comment \\
\hline 649C1-A1 & ATR-1 & $649 \mathrm{C} 1$ & 6.8 & 5.0 & 82 & 2004 & Endcapped \\
\hline 649C1-A2 & ATR-2 & $649 \mathrm{C} 1$ & 6.8 & 5.0 & 82 & 2004 & Endcapped \\
\hline 649C1-A3 & ATR-3 & $649 \mathrm{C} 1$ & 6.8 & 5.0 & 73 & 2004 & Endcapped \\
\hline 649C1-A4 & ATR-4 & $649 \mathrm{C} 1$ & 6.8 & 5.0 & 73 & 2004 & Endcapped \\
\hline 605B8/9-A5 & ATR-5 & $605 \mathrm{~B}-8 / 9$ & 6.8 & 5.0 & $69-72$ & 1995 & Endcapped \\
\hline 605B8/9-A6 & ATR-6 & $605 \mathrm{~B}-8 / 9$ & 6.8 & 5.0 & $69-72$ & 1995 & Endcapped \\
\hline 616C1-A7 & ATR-7 & $616 \mathrm{C} 1$ & 6.8 & 5.0 & 51 & 1997 & Endcapped \\
\hline 616D-A8 & ATR-8 & $616 \mathrm{D}$ & 6.8 & 5.0 & 51 & 1997 & Endcapped \\
\hline 649C1-M1\&H1 & Met-1 \& Heating-1 & $649 \mathrm{C} 1$ & 2.0 & 2.0 & 82 & 2004 & Open-ended \\
\hline 650C1-M2\&H2 & Met-2 \& Heating-2 & $650 \mathrm{C} 1$ & 2.0 & 2.0 & 73 & 2004 & Open-ended \\
\hline 650E2-M3\&H3 & Met-3 \& Heating-3 & $605 \mathrm{E} 2$ & 3.0 & 3.0 & 73 & 2004 & Open-ended \\
\hline 6058/9-M4\&H4 & Met-4 \& Heating-4 & $605 \mathrm{~B}-8 / 9$ & 2.5 & 2.5 & $69-72$ & 1995 & Open-ended \\
\hline 616C1-M5 & Met-5 & $616 \mathrm{C} 1$ & 1.0 & 1.0 & 51 & 1997 & Open-ended \\
\hline 616D-M6 & Met-6 & $616 \mathrm{D}$ & 1.0 & 1.0 & 51 & 1997 & Open-ended \\
\hline
\end{tabular}




\section{References}

1. EPRI report 1001558

2. E-mail communication with Michael Billone at Argonne National Laboratory.

3. INL report INL/EXT-08-14547

4. I.C. Gauld et al., Re-evaluation of Spent Nuclear Fuel Assay Data for the Three Mile Island Unit 1 Reactor and Application to Code Validation

5. 2017 CFA Technical Narrative - DE-FOA-0001515 